\title{
Implementasi Workshop Pengembangan Keprofesionalismean Berkelanjutan Pendidikan Abad 21 untuk Meningkatkan Kinerja Guru
}

\author{
Made Raksa \\ Dinas Pendidikan Pemuda dan Olah Raga \\ Kabupaten Buleleng \\ e-mail:65raksa@gmail.com
}

\begin{abstract}
Abstrak
Tujuan dari penelitian ini adalah untuk mengetahui peningkatan kinerja guru di SDN 1 Silangjana Semester 1 Tahun Pelajaran 2019/2020 setelah mengikuti kegiatan pengembangan keprofesionalismean berkelanjutan pendidikan abad 21. Penelitian ini adalah penelitian tindakan sekolah. Subjek penelitian adalah guru di SDN 1 Silangjana yang berjumlah 8 orang guru. Data kinerja guru pada penelitian ini dikumpulkan menggunakan kuesioner. Teknik analisis data menggunakan analisis deskriptif. Indikator keberhasilan penelitian ini adalah: apabila rata-rata kinerja guru minimal pada kategori Tinggi, dan ketuntasan klasikal sebesar $90 \%$. Berdasarkan penelitian yang telah dilakukan, disimpulkan bahwa melalui pengembangan keprofesionalismean berkelanjutan pendidikan abad 21 dapat meningkatkan kinerja guru di SDN 1 Silangjana Semester 1 Tahun Pelajaran 2019/2020. Hasil ini terbukti dari peningkatan rata-rata siklus I sebesar 145,25 menjadi 172,38 pada siklus II. Ketuntasan klasikal siswa pun mengalami peningkatan dari $75 \%$ pada siklus I menjadi $100 \%$ pada siklus II.
\end{abstract}

Kata-kata kunci: Guru, Workshop, Pendidikan Abad 21

\section{Abstract}

The purpose of this study was to determine the improvement of teacher performance at SDN 1 Silangjana Semester 1 in 2019/2020 Academic Year after participating in activitiy of continuing professionalism development in 21st century education. This study was a school action research. The research subjects were 8 teachers at SDN 1 Silangjana. Teacher performance data were collected with questionnaire. Data were analyzed by descriptive analysis. Indicators of success of this study were: if the average teacher performance was at least in High category, and classical completeness was $90 \%$. Based on research that has been done, it was concluded that through the development of continuing professionalism in 21st century education can improve the performance of teachers at SDN 1 Silangjana Semester 1 in 2019/2020 Academic Year. This result was evident from the increase in the average of first cycle was 145.25 to 172.38 in the second cycle. Classical completeness of students also increased from $75 \%$ in the first cycle to $100 \%$ in the second cycle.

Keywords: Teacher, Workshop, Education in 21st

\section{Pendahuluan}

Perkembangan zaman tentunya memberikan pengaruh yang sangat besar dalam dunia pendidikan. Seiring dengan perkembangan zaman saat ini, guru menghadapi tantangan yang jauh lebih besar dari era sebelumnya. Zaman sekarang ini lebih dikenal dengan Abad 21. Abad 21 merupakan abad pengetahuan, abad dimana informasi banyak tersebar dan teknologi berkembang. Karakteristik abad 21 ditandai dengan semakin bertautnya dunia ilmu pengetahuan, sehingga sinergi diantaranya menjadi semakin cepat. Dalam konteks pemanfaatan teknologi informasi dan komunikasi di dunia pendidikan, telah terbukti dengan semakin menyempit dan meleburnya faktor "ruang dan waktu" yang selama ini menjadi aspek penentu kecepatan dan keberhasilan ilmu pengetahuan oleh umat manusia (BSNP, 2010). Abad 21 juga ditandai dengan banyaknya (1) informasi yang tersedia dimana saja dan dapat diakses kapan saja; (2) komputasi yang semakin cepat; (3) otomasi yang menggantikan pekerjaan-pekerjaan rutin; dan (4) komunikasi yang dapat dilakukan dari mana saja dan kemana saja (Litbang Kemdikbud, 2013).

Untuk menghadapi pembelajaran di abad 21, setiap orang harus memiliki keterampilan berpikir kritis, pengetahuan dan kemampuan literasi digital, literasi informasi, literasi media dan 
menguasai teknologi informasi dan komunikasi (Frydenberg \& Andone, 2011). Sejumlah penelitan tentang pemanfaatan teknologi informasi yang mendukung pembelajaran abad 21 telah dilakukan di berbagai negara. Diantaranya yaitu, teknologi web 2.0 cocok untuk memenuhi sebagian tuntutan yang muncul dari masyarakat pembelajar di abad 21 (Yengin, 2014). Kemudian di Portugal, program aplikasi Scratch berhasil memotivasi siswa sekolah dasar kelas 5 dan 6 dan meningkatkan proses belajarnya. Selain itu juga, program aplikasi Scratch berhasil meningkatkan konsentrasi, kreativitas dan kolaborasi siswa (Pinto \& Escudeiro, 2014).

Untuk mewujudkan apa yang telah disampaikan di atas, tentunya peran pendidik atau guru sangatlah penting. Guru memikul tugas yang sangat berat. Maka dari itu, guru pada abad 21 dituntut keprofesionalismeannya, sehingga nanti mampu menciptakan pembelajaran yang mampu mengikuti perkembangan zaman.

Berdasarkan hal tersebut maka kinerja guru di sekolah harus terus ditingkatkan. Kinerja guru mempunyai spesifikasi/kriteria tertentu. Kinerja guru dapat dilihat dan diukur berdasarkan spesifikasi/kriteria kompetensi yang harus dimiliki oleh setiap guru. Berdasarkan Peraturan Menteri Pendidikan Nasional Republik Indonesia Nomor 16 Tahun 2007 tentang Standar Kualifikasi Akademik dan Kompetensi Guru. Dijelaskan bahwa Standar Kompetensi Guru dikembangkan secara utuh dari 4 kompetensi utama, yaitu: (1) kompetensi pedagogik, (2) kepribadian, (3) sosial, dan (4) profesional. Keempat kompetensi tersebut terintegrasi dalam kinerja guru.

Semua orang mungkin bisa menjadi guru. Tetapi, menjadi guru yang memiliki keahlian dalam mendidik perlu pendidikan, pelatihan, dan jam terbang yang memadai. Dalam konteks tersebut, menjadi guru profesional setidaknya memiliki standar minimal, yaitu: (1) Memiliki kemampuan intelektual yang baik, (2) memiliki kemampuan memahami visi dan misi pendidikan nasional, (3) memahami keahlian mentrasfer ilmu pengetahuan kepada siswa secara efektif, (4) memahami konsep perkembangan psikologi anak, (5) memiliki kemampuan mengorganisasi proses belajar, (6) memiliki kreatifitas dan seni mendidik.

Salah satu sekolah dasar yang harus siap mengantisipasi pendidikan abad 21 adalah SDN 1 Silangjana Semester 1 Tahun Pelajaran 2019/2020. Realita yang terjadi di SDN 1 Silangjana Semester 1 Tahun Pelajaran 2019/2020 adalah masih adanya guru yang memiliki penguasaan IT yang minim, dan guru-guru belum mampu mengaplikasikan pembelajaran inovatif dan kolaboratif di kelas. Permasalahan ini merupakan permasalahan yang harus diatasi dengan optimal guna meningkatkan kinerja guru yang ada di SDN 1 Silangjana.

Untuk mengatasi permasalahan di atas, dapat dilakukan dengan melakukan pengembangan keprofesionalismean berkelanjutan pendidikan abad 21 bagi guru-guru di SDN 1 Silangjana Semester 1 Tahun Pelajaran 2019/2020 berupa kegiatan workshop.

Berdasarkan hal di atas, maka pada penelitian ini akan mengambil judul tentang implementasi workshop pengembangan keprofesionalismean berkelanjutan pendidikan abad 21 untuk meningkatkan kinerja guru di SDN 1 Silangjana Semester 1 Tahun Pelajaran $2019 / 2020$.

Tujuan dari penelitian ini adalah untuk mengetahui peningkatan kinerja guru di SDN 1 Silangjana Semester 1 Tahun Pelajaran 2019/2020 setelah mengikuti workshop pengembangan keprofesionalismean berkelanjutan pendidikan abad 21.

Hipotesis yang diajukan dalam penelitian ini adalah: apabila workshop pengembangan keprofesionalismean berkelanjutan pendidikan abad 21 berjalan dengan maksimal, maka kinerja guru di SDN 1 Silangjana Semester 1 Tahun Pelajaran 2019/2020 dapat ditingkatkan.

\section{Metode}

Penelitian ini dilaksanakan di SDN 1 Silangjana Semester 1 Tahun Pelajaran 2019/2020. Penelitian ini dilaksanakan dari bulan Agustus sampai Nopember 2019. Subjek penelitian adalah guru di SDN 1 Silangjana Semester 1 Tahun Pelajaran 2019/2020 sebanyak 8 orang guru. Sedangkan objek dari penelitian ini adalah kinerja guru dengan mengikuti workshop pengembangan keprofesionalismean berkelanjutan pendidikan abad 21 . Jenis penelitian ini adalah penelitian tindakan sekolah (PTS). Penelitian tindakan sekolah merupakan suatu penelitian yang bertujuan untuk memperbaiki kegiatan-kegiatan yang dilaksanakan di sekolah, sehingga kualitas sekolah dapat ditingkatkan. Peneliti merancang penelitian yang akan dilaksanakan dan menyiapkan instrumen evaluasi/observasi serta mengelola pembelajaran berdasarkan langkah-langkah kegiatan yang digunakan. Penelitian ini direncanakan dalam beberapa siklus, tiap siklus terdiri dari empat tahapan yaitu perencanaan, 
pelaksanaan, observasi, dan refleksi. Jika sudah memenuhi hasil yang diharapkan maka siklus tidak dilanjutkan lagi. Adapun prosedur penelitian tindakan kelas yang dilakukan terdiri dari dua siklus yaitu sebagai berikut.

\section{Rancangan Penelitian Tindakan Kelas Siklus I}

Siklus I dilakukan dalam tiga kali pertemuan. Siklus tersebut mengacu pada empat tahap pelaksanaan PTS. Keempat tahapan tersebut terdiri dari: 1) Rencana tindakan. Agar pelaksanaan pembelajaran dapat diterapkan dengan baik dan sesuai dengan tujuan penelitian yang dirumuskan, ada beberapa hal yang perlu dipersiapkan oleh peneliti, yaitu sebagai berikut. (1) Mengkaji sekolah yang akan diberikan tindakan. (2) Menyiapkan materi yang berkaitan dengan pengembangan keprofesionalismean berkelanjutan pendidikan abad 21. Dan (3) Menyiapkan instrument untuk mengumpulkan data yang diperlukan seperti kuesioner yang digunakan untuk mengetahui kinerja guru. 2) Pelaksanaan tindakan. Pada siklus I ini, tindakan dilakukan tiga (3) $\mathrm{x}$ pertemuan sesuai dengan perencanaan yang telah dibuat sebelumnya, dimana masing-masing pertemuan diatur sesuai perencanaan yang telah dirancang peneliti. 3)

Pemantauan/observasi dan Evaluasi. Pemantauan/observasi dilakukan pada saat pelaksanaan tindakan yang meliputi hal-hal yang berkaitan pelaksanaan tindakan menggunakan lembar pengamatan/observasi. Dan 4) Refleksi. Refleksi diberikan untuk melihat sejauh mana kinerja guru pada siklus I. Berdasarkan hasil refleksi ini digunakan sebagai dasar untuk memperbaiki dan menyempurnakan perencanaan dan pelaksanaan tindakan pada siklus I serta mencari cara untuk memecahkan masalah yang ada, yang selanjutnya akan dirumuskan untuk pelaksanaan siklus selanjutnya.

\section{Rancangan Penelitian Tindakan Kelas Siklus II}

Pada siklus II, dilaksanakan dengan memperhatikan hasil evaluasi pada siklus I dengan memperbaiki tindakan sesuai hasil refleksi siklus I. Tahap penelitian siklus II juga sama seperti siklus I. Dalam penelitian ini digunakan metode pengumpulan data yaitu metode kuesioner. Metode kuesioner merupakan salah satu dari berbagai metode dalam pengumpulan data. Menurut Agung (2010:58), metode kuesioner adalah suatu cara memperoleh data dengan jalan memberikan kuesioner kepada responden, dan responden mengisi kuesioner tersebut sesuai dengan kenyataan atau realita yang ada. Dalam penelitian ini, metode kuesioner digunakan untuk mengumpulkan data tentang Kinerja guru. Kuesioner yang dibuat menggunakan skala likert 1-5, sehingga data yang diperoleh berupa skor. Analisis data yang digunakan pada penelitian ini adalah metode analisis statistik deskriptif kuantitatif.

\section{Hasil dan Pembahasan}

Pendidikan Nasional abad 21 bertujuan untuk mewujudkan cita-cita bangsa, yaitu masyarakat bangsa Indonesia yang sejahtera dan bahagia, dengan kedudukan yang terhormat dan setara dengan bangsa lain dalam dunia global, melalui pembentukan masyarakat yang terdiri dari sumber daya manusia yang berkualitas, yaitu pribadi yang mandiri, berkemauan dan berkemampuan untuk mewujudkan cita-cita bangsanya (BSNP, 2010).

P21 (Partnership for 21st Century Learning) mengembangkan framework pembelajaran di abad 21 yang menuntut peserta didik untuk memiliki keterampilan, pengetahuan dan kemampuan dibidang teknologi, media dan informasi, keterampilan pembelajaran dan inovasi serta keterampilan hidup dan karir (P21, 2015). Framework ini juga menjelaskan tentang keterampilan, pengetahuan dan keahlian yang harus dikuasai agar siswa dapat sukses dalam kehidupan dan pekerjaanya.

Berdasarkan penelitian yang dilakukan dengan mengimplementasikan workshop pengembangan keprofesionalismean berkelanjutan pendidikan abad 21 pada guru-guru di SDN 1 Silangjana Semester 1 Tahun Pelajaran 2019/2020 mendapatkan hasil pada siklus I rerata kinerja guru adalah 145,25 dan berada pada kategori tinggi. Persentase ketuntasan klasikalnya adalah $75 \%$. Hal tersebut dikarenakan 2 orang mendapatkan skor yang berdada pada kategori sedang. Kendala yang dihadapi pada siklus I adalah guru masih belum mampu menguasai teknologi informasi dan komunikasi dengan baik, dan guru belum mampu mengembangkan materi pembelajaran yang diampu secara efektif.

Berdasarkan pemaparan di atas, kategori kinerja guru berada pada kategori tinggi dan ketuntasan guru tidak mencapai $90 \%$ sehingga belum mencapai kategori dan ketuntasan yang ditetapkan oleh peneliti, yakni kategori kinerja guru berada pada kategori minimal tinggi dan dan 
kentutasan klasikal 90\%. Sehingga dapat disimpulkan bahwa siklus I belum berhasil dan harus diadakan siklus II dengan memperhatikan kendala-kendala yang dihadapi siklus I.

Upaya yang dilakukan untuk mengatasi kendala siklus I adalah memberikan kesempatan guru untuk berlatih menggunakan teknologi informasi dan komunikasi dan memberikan ruang diskusi lebih lama dalam hal mengembangkan materi pembelajaran yang diampu oleh masingmasing guru.

Pada siklus II rerata kinerja guru meningkat menjadi 172,38 dan berada pada kategori sangat tinggi. Persentase ketuntasan klasikalnya adalah $100 \%$. Hal ini menunjukkan bahwa kendala-kendala yang dihadapi pada siklus I sudah dapat diatasi pada siklus II. Maka dari itu kriteria ketuntasan minimal baik dan ketuntasan klasikal 90\% sudah terpenuhi sehingga penelitian pada siklus II dinyatakan berhasil dan siklus dihentikan.Untuk lebih jelasnya, peningkatan dari siklus I ke siklus II dapat digambarkan dalam grafik berikut.

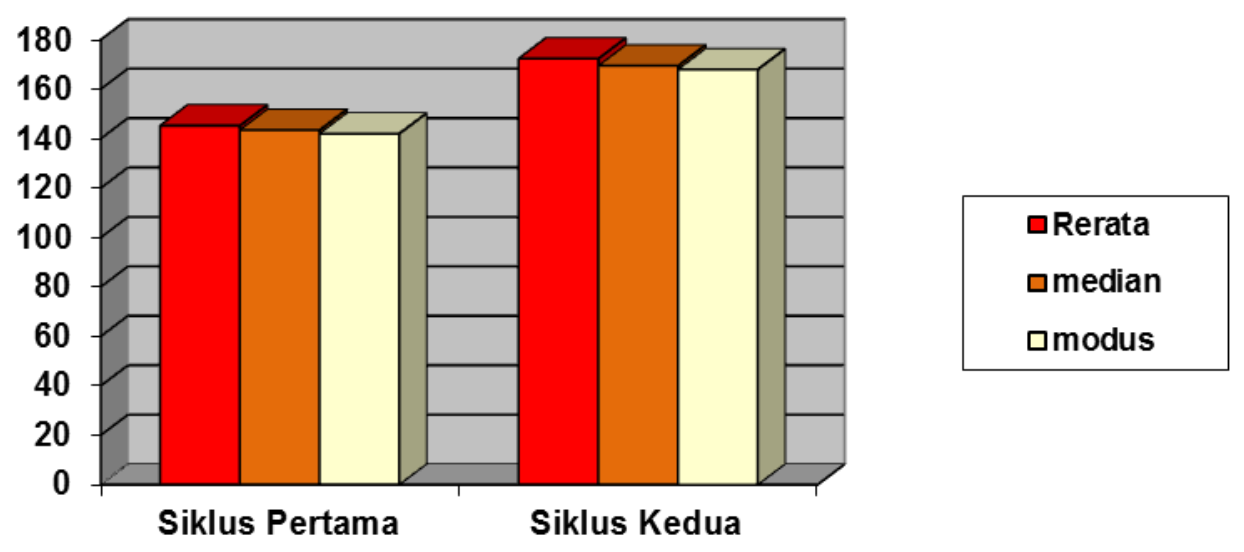

Gambar. 01 Kinerja Guru pada Siklus I dan Siklus II

Sedangkan ketuntasan klasikal tindakan siklus I dan siklus II dapat digambarkan pada gambar berikut.

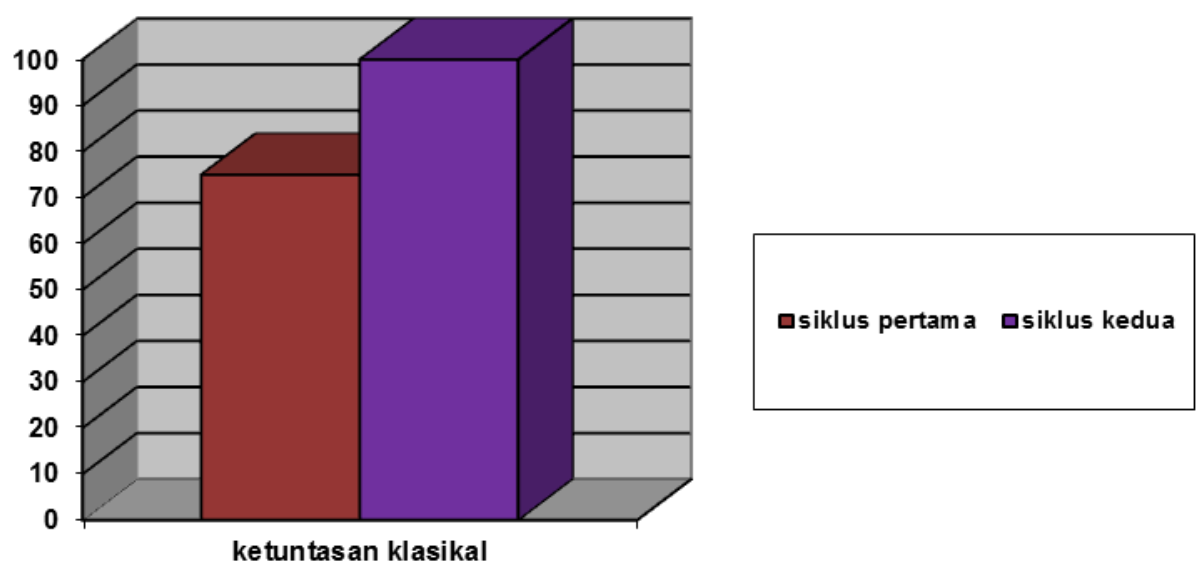

Gambar. 02 Ketuntasasn Klasikal Siklus I dan Siklus II

Berdasarkan Gambar 01 dan 02 terlihat peningkatan yang signifikan antara kinerja guru pada dari siklus I ke siklus II sehingga dapat disimpulkan bahwa workshop pengembangan keprofesionalismean berkelanjutan pendidikan abad 21 secara efektif dapat meningkatkan kinerja guru di SDN 1 Silangjana Semester 1 Tahun Pelajaran 2019/2020.

Kegaitan workshop akan mambatu guru untuk lebih mengembangakan pengetahuan serta meningkatkan kemapuan profesionalnya. Karena dengan kegiatan ini guru akan menambah keterampilan dalam penggunakan teknologi terkini, yang mana perkembangan teknologi dalam bidang pendidikan sangat pesat. Sehingga seorang guru bisa belajar dan mendapatkan sumber-sumber belajar yang lebih banyak. Dengan pengalaman yang 
diperolehnya, seorang guru akan lebih tertarik akan sesuatu yang ada hubungannya dengan kinerja. Dengan adanya workshop ini guru akan mendapatkan banyak pengalaman dan pengetahuan yang tidak diketahui sebelumnya, sehingga guru mampu mengembangkan kinerjanya.

Hasil penelitian ini sejalan dengan hasil penelitian yang dilakukan oleh Heti Murniayudi, dkk (2018) dengan judul Reciprocal teaching: Sebuah inovasi pembelajaran abad 21 untuk meningkatkan pemahaman konsep mahasiswa PGSD. Keberhasilan penelitian ini dapat ditunjukkan melalui hasil tes siklus I menunjukkan persentase sebesar $75,3 \%$ pada indikator menafsirkan, dan persentase sebesar $81,7 \%$ pada indikator menjelaskan. Kemudian setelah dilaksanakan tindakan siklus II diperoleh persentase sebesar $78 \%$ pada indikator menafsirkan dan persentase sebesar $76,9 \%$ pada indikator menjelaskan. Pada siklus III terjadi peningkatan persentase sebesar $95,3 \%$ pada indikator menafsirkan, dan persentase sebesar $85,1 \%$ pada indikator menjelaskan. Dengan melihat hasil yang diperoleh pada setiap siklusnya, maka dapat diambil kesimpulan bahwa penerapan model pembelajaran reciprocal teaching dapat dapat meningkatkan pemahaman konsep IPS pada mahasiswa PGSD.

Jadi dapat dikatakan bahwa dengan adanya workshop pengembangan keprofesionalismean berkelanjutan pendidikan abad 21 mampu meningkatkan kinerja Guru.

\section{Simpulan dan Saran}

Berdasarkan hasil penelitian yang telah dibahas pada bab IV, maka dapat disimpulkan bahwa implementasi workshop pengembangan keprofesionalismean berkelanjutan pendidikan abad 21 dapat meningkatkan kinerja guru di SDN 1 Silangjana Semester 1 Tahun Pelajaran 2019/2020. Hasil ini terbukti dari peningkatan rata-rata siklus I sebesar 145,25 menjadi 172,38 pada siklus II. Ketuntasan penelitian pun mengalami peningkatan dari $75 \%$ pada siklus I menjadi $100 \%$ pada siklus II.

Saran yang dapat diajukan melalui penelitian ini adalah 1) Guru disarankan untuk bekerja dengan sepenuh hati dan menunjukkan kinerja terbaik sehingga peserta didik menjadi nyaman dan senang dalam belajar, dan 2) Kepala sekolah disarankan untuk selalu mendukung peningkatan sumber daya manusia yang ada di sekolah, sehingga tujuan pendidikan dapat tercapai secara optimal.

\section{Daftar Pustaka}

Agung, A.A Gede. 2010. Metodologi Penelitian Pendidikan. Singaraja: Fakultas Ilmu Pendidikan Universitas Ganesha.

BSNP. 2010. Paradigma Pendidikan Nasional Abad XXI.

Darling, Linda., H. (2006). Constructing 21st century teacher education. Journal of teacher education, 57. 300-314.

Frydenberg, M., \& Andone, D. 2011. Learning for 21 st Century Skills, 314-318.

Hargreaves, Andy. 1997. The four ages of professionalism and professional learning. UNICORN, 23(2). 86-114

Lai, C.-L., \& Hwang, G.-J. 2014. Effects of Mobile Learning Participation Time on High School Students' 21st Century Core Competences. 2014 International Conference of Educational Innovation through Technology, 205-211. http://doi.org/10.1109/EITT.2014.40

Litbang Kemdikbud. 2013. Kurikulum 2013: Pergeseran Paradigma Belajar Abad-21. Retrieved September 29, 2015, from http://litbang.kemdikbud.go.id/index.php/index-beritakurikulum/243-kurikulum-2013-pergeseran-paradigma-belajar-abad-21

Mulford, B. 2008. The leadership challenge: improving learning in schools. Australian Education Review. Victoria: ACER Press.

Murniayudi, Heti, dkk. 2018. Reciprocal teaching: Sebuah inovasi pembelajaran abad 21 untuk meningkatkan pemahaman konsep mahasiswa PGSD. E-Jurnal Premiere Educandum (Jurnal Pendidikan Dasar dan Pembelajaran) Volume 8(2) 173 - 184 Desember 2018 Copyright O2018 Universitas PGRI Madiun ISSN: 2088-5350 (Print) / ISSN: 2528-5173 (Online).

Nino, M., \& Evans, M. 2015. Fostering 21st-Century Skills in Constructivist Engineering Classrooms with Digital Game-Based Learning. IEEE Revista Iberoamericana de 

$\begin{array}{lrrr}\begin{array}{l}\text { Tecnologias } \\ \text { http://doi.org/10.1109/RITA.2015.2452673. }\end{array} & \text { Aprendizaje, } & \text { 8540(c), } & \text { 1-1. }\end{array}$

P21. 2015. Framework for 21st Century Learning. Retrieved September 28, 2015, from http://www.p21.org/storage/documents/docs/P21 Framework Definitions New Log o 2015.pdf

Pinto, A., \& Escudeiro, P. 2014. The Use of Scratch for the Development of 21st Century Learning Skills in ICT. In Information Systems and Technologies (CISTI), 2014 9th Iberian Conference on (pp. 1-4). Barcelona: IEEE. http://doi.org/10.1109/CISTI.2014.6877061

Tamimudin H, M. 2013. E-Learning dan Pembelajaran Abad 21 (Best Practice E-Learning PPPPTK Matematika). In Seminar Nasional Pemanfaatan TIK Menyongsong Implementasi Kurikulum 2013.

Yengin, I. 2014. Using Educational Technology to Create Effective Learning Societies in 21st Century. In Information Technology Based Higher Education and Training (ITHET) (pp. 1 - 7). York: IEEE. http://doi.org/10.1109/ITHET.2014.7155689.

Ning Zahroh, Mas. 2016. Evaluasi Kinerja Guru dalam Peningkatan Mutu Pendidikan di Yayasan Al Kenaniyah Jakarta Timur. Jurnal Manajemen Pendidikan. https://www.neliti.com/id/publications/. Diakses 17 Mei 2019.

Ode Ismail Ahmad, LA. 2017. Konsep Penilaian Kinerja Guru Dan Faktor Yang Mempengaruhinya. Jurnal Idaarah Vol. I No. 1. http://journal.uinalauddin.ac.id/index.php/. Diakses 17 Mei 2019.

Purwanto. 2011. Evaluasi Hasil Belajar. Yogyakarta: pustaka pelajar.

Rahadi, Ansto. 2003. Media Pembelajaran Jakarta : Dikjen Dikti Depdikbud.

Slameto, Bambang S, dkk. 2017. Peningkatan Kinerja Guru melalui Pelatihan beserta Faktor Penentunya. Jurnal Pendidikan IImu Sosial Vol. 27 No. 2 Hal. 38-47. http://journals.ums.ac.id/index.php/. Diakses 17 Mei 2019.

Srinalia. 2015. Faktor-Faktor Penyebab Rendahnya Kinerja Guru dan Korelasinya terhadap Pembinaan Siswa: Studi kasus di SMAN 1 Darul Imarah Aceh Besar. Jurnal IImiah Didaktika Vol. 15 No. 2. https://media.neliti.com/media/publications/. Diakses $17 \mathrm{Mei}$ 2019.

Sudjana. 2001. Media Pengajaran. Jakarta : Sinar Baru Algensindo.

Zubair, Ahmad, dkk. 2017. Manajemen Peningkatan Kinerja Guru. Manajer Pendidikan, Volume 11 Nomor Hal. 304-311. https://media.neliti.com/media/publications/. Diakses $17 \mathrm{Mei}$ 2019. 